\title{
SUB-CONJUNCTIVAL ADVANCEMENT
}

\section{George Young, COLCHESTER}

I have used the following simple process in advancing either the external, or the internal rectus muscle of the eye, in convergent or divergent strabismus, with or without muscular asthenopia, alone or in connection with tenotomy of the antagonist, with such good results, as to lead me to think it worthy of consideration.

A drop of pure adrenalin, 1:1000, is instilled, and repeated in a couple of minutes, whereupon the conjunctival sac is anaesthetized, with $2 \%$ holocain. Two instillations, about two minutes apart, suffice.

The speculum firmly fixed, a tiny opening is made in the "conjunctiva and sub-conjunctival tissue, at $\mathrm{X}$, with a straight canaliculus

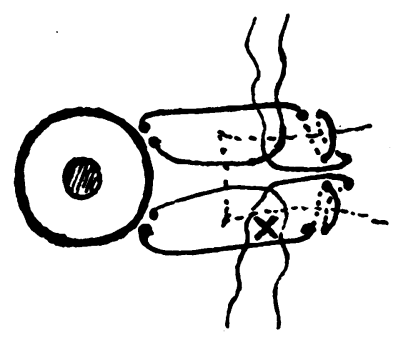

knife, which has a convex sweep to its cutting edge, and which is passed through this opening and under the rectus tendon, the sclera is rasped from the tendon insertion for about tin. backwards, by turning the cutting edge towards it, and making half a dozen good to and fro movements with the cutting edge lightly pressed on to the sclera. Then the edge is reversed through $180^{\circ}$, and the under surface of the tendon and muscle belly are rasped in the same way for double the above distance, or more, as the case may require lesser or greater shortening.

Two strong silk sutures are inserted in double loops through the whole conjunctiva and muscle belly, one through its upper half, and the second through its lower half, and are again passed through corresponding points at the limbus, where not only conjunctiva, but half the thickness of the sclera is taken up on the point of the needle. The two sutures, tied and firmly drawn together, will tuck the muscle on itself. The forward half of its rasped under surface will be doubled on itself and will grow together, while the rest of its rasped under surface will adhere to that portion of the sclera which 
has been also rasped. Both eyes are tied up for five days, and the stitches left in as long as one can. I leave them at least two weeks.

The sole disadvantage is the marked hump or pucker which is left by this tuck. I found it flattened down, however, and ceased to be at all unsightly in a few months. Everything else seems to me to be an advantage. Its simplicity, sub-conjunctival character, painlessness, speed, and above all its leaving the tendon uncut, and the chance of future greater advancement, if need be. Its effect is very powerful, and can be made more or less so by inserting the loops further back or further forward through the muscle, and by drawing the sutures more or less tightly together, on tying them.

The passing of the loops is a little painful, but even this can easily be avoided by. an intramuscular injection.

\section{INTERNATIONAL CONGRESS OF OPHTHALMOLOGY}

BEAUTIFUL weather favoured the International Congress of Ophthalmology held at Washington in the last week of April. The City of White Marbled Halls, statued monuments and shady avenues, decked out with spring green foliage, was looking its best.

Two days before the opening meeting the promoters of the Congress received a nasty shock, due to a fire breaking out in the New Willard Hotel, where its headquarters were situated, in what was to have been the meeting room. Some members of the Congress who had already taken up their residence at the hotel were awakened by telephone in the early hours of the morning, advised to dress quickly and descend by the elevators. The famous Peacock Alley of the hotel soon becamecrowded with guests in various degrees of negligée, holding hand luggage containing their most valued possessions. Fortunately the fire was confined to the tenth floor of the building, and was extinguished within an hour. Though the rooms in one of the other floors were rendered uninhabitable by damage from water, the members of the Congress who flowed into the hotel during the next few days were all accommodated.

The proposed meeting room in the hotel having been destroyed, the opening meeting of the Congress and the Scientific Sessions on the first three days were held in the spacious and beautiful hall belonging to the Daughters of the American Revolution. As this hall could not be utilized for lantern demonstrations during the day time, the final meeting was held at the building of the Medical Society of the District of Columbia. 